\title{
Introduction to The Changing Ethos of Human Rights
}

\section{Hoda Mahmoudi}

\section{CONSIDERING HUMAN RIGHTS}

Human rights define us. They capture, at various moments, the grand accomplishments and stunning failures of the human species. Human rights encompass both reach and limit, possibility and impossibility. They tell the fraught story of the grand human narrative and invite us to consider our place in it. When human rights are acknowledged, whether by local community or international council, an implicit optimism is present. When human rights are sought, through scholarship, civic action, or legislative activity, an ethic of human care emerges.

This edited volume surveys the changing ethos of human rights in our modern moment and traces its recent histories and processes of change; it delineates the ethical, moral, and intellectual shifts in a changing human rights zeitgeist. Most importantly, this edited volume tries to determine how we - as individuals, communities, institutions, and nations - can examine the broad questions of human rights and human dignity. These questions, again, are anything but simple. Such questions are questions of faith, practice, science, history, and much more. These questions also define how "our very relationships are structured by patterns of power, which also structure how we view, define, and solve global moral and political problems" (Greenswag, 2017: 802). Such questions matter to people everywhere. For who we are, how we live, and to whom we owe allegiance to are notions that matter to every nationality and philosophical outlook. This is why there must always be a debate on these questions. 


\section{DEFINING HUMAN RIGHTS}

If the "human" in human rights speaks to the notion of a shared, indivisible inheritance, the "rights" of human rights speaks to the sharing of that inheritance. Human rights links inherent human value to the freedoms of human activity. In this equivalency, human life is a resource; human activities animate and advance that resource. Human rights thus become the living deployment of human ability and potential. This link between the ontology of human life and the epistemology of human activity shows why human rights are so important. Human rights matter because the struggle for human rights is nothing less than the struggle to preserve human dignity and advance human potential.

In the 500 years since the Enlightenment, the notion of human rights has shifted significantly. There is increased recognition of the inherent value of human life, as the idea of human rights has gained credence. Discovery, invention, and the advancement of science have dramatized the landscape of human rights, making both accomplishment and failure more vivid.

Horrible diseases and intractable social problems have been reduced. The fraught poverty that defined human life for millennia has been eased, while life expectancy has soared. Yet mechanized warfare, increased global pandemics, and the ability to obliterate the entire human race also define our era. For every Nelson Mandela there has been an Idi Amin, for every Martin Luther King a Pol Pot. The herculean efforts to build durable institutions devoted to human rights are laudable, and should be saluted and studied. Yet fundamental challenges continue.

Examining the shifting zeitgeist of human rights approaches reveals ethical and moral shifts in our thinking about human life. Such a survey gives scholars an opportunity to examine the ways in which human rights have changed over time. Examining human rights through an ethical and moral lens also allows us to trace intellectual and cultural changes. Histories of human rights, and their concomitant arguments and activities, reveal the mode and movement of an age; these histories also reveal the beliefs which animate us.

As James McPherson (1988: 866-77) described so eloquently within the context of the American Civil War, societies need both a freedom from and a freedom to. In his imagining, the freedom from described the energies of the Union army; the freedom to described the energies of the Confederate army. The Union army fought for a freedom from bondage 
for all men and women, while the Confederate army fought for the freedom to do as they wished.

These notions of dueling freedoms touch on fundamental questions that undergird any vision of ethics and morality. What is the fundamental relationship between me and others? To whom do I owe allegiance, and why? Ethics-of-care approaches suggest that it is only when personal concerns and freedoms are braided with communal concerns and freedoms that a participatory, egalitarian, cooperative, and prosperous society is created. Only the conjoining of a harmonious social and moral life can create a society where

the need for law and coercion would not disappear, but their use might become progressively more limited as society would learn to bring up its children so that fewer and fewer would sink to violence or insist on pursuing their own individual interests at the expense of others or without reasonable restraints. (Held, 2002: 172)

\section{THE ETHOS OF RIGHTS AND THE ETHICS OF CARE}

Ethics-of-care approaches to human life are one way to consider the broad narrative of human rights and the grand work of human rights; these approaches are a critical part of the changing ethos of human rights. Ethics-of-care approaches attempt to create a universal rendering of human value and provide a methodology for how to secure such human value in the real world. More than any other development since the United Nations Declaration of Human Rights, ethics-of-care approaches to human rights demonstrate the shifting zeitgeist of human rights. As Virginia Held explains,

An ethic of care focuses on attentiveness, trust, responsiveness to need, narrative nuance, and cultivating caring relations. Whereas an ethic of justice seeks a fair solution between competing individual interests and rights, an ethic of care sees the interests of carers and cared-for as importantly intertwined rather than as simply competing. Whereas justice protects equality and freedom, care fosters social bonds of cooperation. (Held, 2006a: 15)

As a theory, ethics of care posits that all individuals have given or received acts of love and care. The theory then looks to build upon such acts as a platform for describing, preserving, and advancing human rights. Within an ethics-of-care framework, each individual's life is 
deeply relational - a web of intertwined, caring connections. Or as Fiona Robinson explains, "Human life as we know it would be inconceivable without relations of care" (Robinson, 2011: 2).

The theory of ethics of care began as a feminist critique of male-dominated, objectivist notions of human rights. ${ }^{1}$ But though the theory began as a feminist critique, it grew to trace more broadly the perspectives of neglected and marginalized others, especially those primarily responsible for the care and development of others - a role that often includes minorities and subjugated groups. Oftentimes, it is these groups who are most responsible for providing an individual's first example of loving, human concern. Ethics-of-care theories examine how the experiences of marginalized individuals (based on national, economic, political, or international relationships) are often excluded when one imagines what a truly reformative human rights vision might look like. Ethics-of-care theories articulate an inclusionary vision that celebrates the contributions of all.

Critiques of ethics-of-care approaches argue that the notion of ethical nurturing among individuals essentializes women's contributions and reinforces stereotypes about women's and minorities' supposed "natural" inclinations. But ethics of care does not judge the nature of caretaking inasmuch as it asserts caretaking's value, credibility, and human meaning. Within an ethics-of-care framework, the bonds of peace, secured and advanced by one's natural commitments to others, are best forged by parties who hold significant stakes in community outcomes. And women, though perhaps not often the cause of intra-national wars, are often the beginning and ending engine of intra-community peace (Bunch, 2004: 32-3; Timothy, 2004). Women, along with other marginalized groups, are often looked to when all else has failed. For instance, in the 2020 pandemic brought on by the Covid-19 virus, women and minorities are overrepresented among frontline hospital and service workers. Their heroic efforts of care, often in the midst of danger, are shining examples of courage and conviction.

Tronto and Fisher (1990: 40) define ethics of care broadly. They interpret care as "a species of activity that includes everything we do to maintain, contain, and repair our 'world' so that we can live in it as well as possible. That world includes our bodies, ourselves, and our environment." For Tronto, "Caring requires that one start from the standpoint of the one needing care or attention. It requires that we meet the other morally, adopt that person's, or group's, perspective and look at the world in their terms" (1993: 19). Connections between individuals, 
or what Robinson refers to as relationality, are "a claim about the most basic nature of human social existence. Beyond the claim that humans are 'social beings,' the relational ontology of care ethics claims that relations of interdependence and dependence are a fundamental feature of our existence" (Robinson, 2011: 4). Robinson is arguing that the act of caring for others is a moral act rather than a set of principles or universal directives, and that our responsibilities to others are realized through acts of care.

Fundamentally, care ethics theories seek a new conception of human security and well-being within an interdependent global world. Care ethics considers human life to be vulnerable to societal pressures and strictures, and so the approach seeks to identify the causal agents that produce political, social, and economic conflict. Viewing the international order as an organic community, care ethics examines the systemic forces that promote inequalities and perpetuate exclusivity. Within a care ethics framework, the existing global order is a place where institutions dominate, marginalize, and exclude others. Yet ethics-of-care approaches often do not specify how to eliminate all violations of human rights they instead seek to build on that legacy of ethical and moral caretaking already extant in societies.

In seeking to draw attention to local norms and pre-existing practices, care ethics also reimagines international relations between states by insisting upon cooperative values. Under an ethics-of-care framework, cooperation is a replacement for systems of hierarchy and domination based on gender, race, ethnicity, religion, and class (Held, 2006a). In comparing the ethics of care with the ethics of justice, Held observes that any comprehensive moral theory will embrace insights from both perspectives (as well as other relevant perspectives),

rather than that either of these can be incorporated into the other in the sense of supporting that it can provide the grounds for the judgements characteristically found in the other. Equitable caring is not necessarily better caring, it is fairer caring. And humane justice is not necessarily better justice, it is more caring justice. (Held, 2006a: 16)

Ethics-of-care conceptions of human rights hold that the way we care for one another as individuals and communities becomes the way we care for one another as nations and states. One can imagine what may have happened if the United Nations Declaration began here, with a more relational, care-first approach. Such an approach would have followed the 
extant successes of diverse groups of people and nations and women and minorities. The difficult circumstances of World War II notwithstanding, imagining a solution to these challenges reveals that the battle for human rights is always fraught and complex, filled with divergent political views about the meaning of human rights itself. Yet if we are to imagine a successful future, we must also imagine the different potentials of the past.

Virginia Held reminds us that the central focus of the ethics of care "is on the compelling moral salience of attending to and meeting the needs of the particular others for whom we take responsibility" (Held, 2006a: 10). And moral salience is not always a rational act. Ethics-of-care theories call for the inclusion of emotion and sentiment; the theory differs from dominant normative moral theories that call for moral agents to be emotionally detached (that is, Emmanuel Kant, Jeremy Bentham, John Stuart). Instead, care ethics encourages emotional responses to others; an emotional response to others amplifies moral understanding. Moral understanding in turn motivates action. Ethics of care thus promotes compassion, sympathy, and concern-in-action (Eisenberg and Fabes, 1998; Nussbaum, 2001). It seeks to harness the fuel of compassion to power the engine of action by linking ethics to human activity. Or as noted by Jane Addams, "action is indeed the sole medium of expression for ethics" (Addams in Hamington, 2001: 119; Held, 2006b). In ethics of care, caring for others is a moral responsibility not only performed for those closest to us but to others beyond our circle - particularly in relation to the defenseless, helpless, and powerless. It "respects rather than removes itself from others with whom we share relationships" (Held, 2006a: 11).

Ethics of care also provides a way to address the complex, dynamic relationship of global interaction. Like a butterfly that takes off in one part of the world and influences weather patterns in another part of the world, the mechanisms of ethics of care may be difficult to trace, but the influence of care on human beings remains clear. As Herring (2017: 166) notes, "Supporters of an ethic of care argue that, rather than the primary focus of the legal or ethical enquiry being whether it 'is my right to do X?', the question should be 'what is my proper obligation within the context of this relationship?"' (Herring, 2017: 166). This kind of ethics-of-care chaos theory compels us to develop new methodologies and approaches for tracking and tracing the impact of care networks. Such a differentiated approach would seem to call less for statutory approaches than for supra-legal applications beyond national, ethnic, or religious borders. In this sense, ethics-of-care conceptions are funda- 
mentally "a criticism of the conceptually imperialistic role that law has played in moral thinking" (Held, 2006a: 141). While upholding human rights through legal means is important, care ethics challenge "the view that imagines law and legal ways of thinking to be suitable for all moral problems" (Held, 2006a: 141).

Perhaps most importantly, care ethics reveals that we are cared for not by "citizens" or "non-citizens" but by individuals devoted to us. The act of caring ensures the survival, development, and social functioning of individuals; it makes no distinction between citizens and non-citizens. Care ethics "argues that human autonomy can be achieved only through good relations of care" (Robinson, 2011: 62). And good relations of care only exist in systems where individuals are devoted to others. Acts of caring, whether by individuals, groups, or nation-states, function as tools of reciprocity - they define human rights in relation to the peace and security of everyone (Held, 2006a: 139). The sense of duty to others creates solidarity with others. Caring becomes an inclusive act, a responsibility shared.

As opportunities for cooperation are enlarged and their benefits perceived, the application of altruism is no longer limited to a small band of close relatives. Particularism is diluted as the community expands. More and more people are recognized, first as fellow-creatures and then as colleagues or members of the same in-group. In the modern nation-state the particularistic connotations of 'citizen,' though far from lost, are greatly attenuated. (Selznick, 1992: 194)

Held explains that "what ethics of care offers is an appreciation of the possibilities for nonviolence and of countering violence in appropriate ways" (Held, 2006a: 139). This is accomplished not by dictating to others but by seeking out terms of consignment and agreement. In this, ethics of care offers hope for the human rights challenges of our time.

\section{THE ORGANIZATION OF THE BOOK}

This book uses an interdisciplinary approach to examine the changing ethos of human rights, with an underlying focus on the ethics of care. Each author identifies a particular human rights challenge; these challenges are then examined from theoretical, philosophical, political, psychological, and spiritual points of view. Each author seeks to develop potential answers, approaches, and practices to further the cause of human rights. 
Michael Penn, in "Values and Human Rights: Implications of an Emerging Discourse on Virtue Ethics", explores how virtue ethics has focused the attention of human rights theorists on concepts that had long been neglected or insufficiently explained by other moral theories, such as utilitarianism and deontology. He explains that what renders virtue ethics unique is that it concerns itself primarily with individuals' moral selves, as opposed to moral laws. This emphasis on the development and refinement of the self has contributed to a renewed search for both those universal values that best facilitate well-being, as well as those indices of character development that are recognized around the world and across traditions as indicative of moral maturity. Furthermore, human rights theorists have also begun to draw from the literature on virtue ethics in their attempts to explicate and justify human rights claims. The chapter explores the main features of this trend and endeavors to examine its potential implications for human rights theory and practice.

The book continues with Samuel Kerstein, who explores the ethos of human rights by examining how a determined notion of dignity can shape ideas about human rights. In his chapter "Dignity and Treating Others Merely as Means," Kerstein discusses Kant's notion of human dignity (the obverse of treating people as means-to-an-end). The chapter reveals that although Kant's theory remains historically contested, we can examine shifting human rights paradigms through this lens. Important issues of our day, such as moral permissibility in bioethics and physician-assisted suicide, can be viewed as debates on Kant's notion of dignity-as-means.

In the chapter "Making Rights Rhetoric Work: Constructing Care in a Post-Liberal World," Alison Brysk examines the viability and power of rhetoric in a post-liberal world. The global rights/human rights movement has grown through a politics of persuasion, including appeals to altruism, cosmopolitanism, and interdependence. But in today's world of declining liberalism, fundamental rationales have been challenged. Brysk argues for expanding a feminist perspective and ethics-of-care approach that seeks to further global human rights.

Parvati Raghuram, in her chapter "Race and Feminist Care Ethics: Intersectionality as Method,"2 argues that gender has been privileged as the optic through which care ethics has been theorized. Her argument pushes further, noting the intersectionality of gender with race, class, and disability and the ways in which racialized difference affects care practices and therefore care ethics. 
In the chapter "Difficult Care: Examining Women's Efforts in the Islamic Republic of Iran," 3 Hoda Mahmoudi describes women's activities in modern-day Iran. The chapter examines care ethics as practiced by women within the Islamic Republic of Iran and the difficulties and victories they encounter. In her chapter, Mahmoudi seeks a broader framework for understanding how women's caring practices function as an unseen edifice of political, cultural, and artistic creation. She demonstrates how ethics of care can function as a prism from which to view sequestered worlds. The chapter argues that though the scholar's ability to identify ethical care is limited, the reality, practice, and furtherance of ethical care among individuals is not limited. The chapter reminds readers that the possibilities of transformation and reformulation exist even within difficult circumstances, and that though ethical care may not be able to be examined directly, its presence can be inferred wherever we view viable, affectionate, and determined communities.

Kate Seaman explores the ethical implications of how new technologies are being utilized in defense of human rights. In her chapter, "Empathy, Caring, and the Defense of Human Rights in a Digital World," Seaman observes that in many cases, new technologies are enabling human rights defenders to raise awareness, secure information, and organize institutions. She explains how digitization also presents challenges, as the democratization of digital collection means that individuals can now be threats to a particular state's interests. Utilizing an ethics-of-care approach, the chapter examines how technology is altering the web of human rights relationships and reshaping the ethos of human rights itself.

Matthew Weinert's "Cultural Heritage, Cultural Rights and Care Ethics" claims that the perception that cultural rights are lesser forms of rights persists. Seeking to counter this notion, the United Nations Human Rights Council created the position of Special Rapporteur to clarify the meaning of cultural rights. This chapter describes the content of this 2009 edict and provides an overview of cultural rights. The chapter describes how technology promotes cultural rights vis-à-vis its care for tangible and intangible cultural heritage. Yet, technology also transports heritage from specific geographic locations, and disrupts historical notions of culture. Despite these disruptions, this chapter argues that technological shifts have the capacity to generate new opportunities for intercultural understanding and cultural respect; technology's ability to present examples of human ingenuity reveals the expressive, creative, and social prospects within human rights. 


\section{CONCLUSION}

Attempting to forge a global approach to human rights raises questions that are at the heart of what it means to be human. Are human beings best understood within statutory and legal systems? Or are human rights best understood within personal, ethical frameworks? What are the implications of the answers to these questions in helping us to conceive of human value, human activity, and human commitment?

These contrasting conceptions of human beings will determine what any approach to human rights will be. Human rights considerations that examine human life as part of a networked system may lack elasticity and nuance; human rights considerations that view human life as individual and private may lack an all-encompassing global approach.

However we define them, human rights, and the ethical and moral systems which accompany them, cannot be separated from social life. Morality's first task is to examine pre-existing moral arrangements and consider how they might be improved. For the scholar interested in a changing human rights zeitgeist, he or she must examine how moral orders "inhere in and are reproduced by inter-actions between people, and how moral orders are concretely embodied in social ones" (Walker, 1998: 11). Discovering how moral orders are concretely embodied in social ones requires the full use of all applicable research methods and a truly interdisciplinary spirit of learning.

Ethics of care provides such an interdisciplinary spirit of learning and understanding. It also allows us to maintain the human in human rights. The theory prescribes a way to draw on the collected wisdoms of all people, tribes, and nations in order to develop a far-reaching human rights platform that can secure the rights and dignity of all. In the interconnected 21st-century community of peoples and nations, understanding the complexities and challenges surrounding human rights is vital to constructing a more just world. Political theorist Iris Young (2011: 136) reminds us that:

No philosopher who restricts the scope of obligation of justice to members of the same nation-state believes that there are no moral obligations that extend beyond borders. Most people are ready to agree that human beings have some moral obligations to other people just because they are human.

Young's notion that we all have moral obligations to one another "just because" we are human requires a serious and dedicated system of con- 
sciousness-raising - consciousness about the sacred worth and dignity of human life. Part of that consciousness-raising involves warning of the dangers that can occur when we do not value human life. To this end, learning about humanity's past atrocities can be instructive. To dwell on the past, however, without a vision for the future is to consign oneself to a mere observer; it strips us of the full, participatory potential of the creative human spirit.

In order to advance and preserve human rights, we must determine what there is to advance and preserve in human beings - in human families, communities, and nations. Secondly, we must ask ourselves what, and who, needs to be assuaged and renewed. Where are the wounds, and where are the wounded, and how can those with resources - whether relational, material, or ethical - help those in need? Finally, we must ask ourselves what there is to be consecrated. Where are the places, and who are the people, who need to be gathered together to remember, and to be dedicated anew?

Over time, the moral framework set forth by ethics of care has drawn attention to inequalities in the lives of those people who in every society have been ignored or overlooked by more traditional approaches to human rights. These vulnerable groups include women, the poor, minorities, and those with disabilities, among others. Care ethics' attention to human interdependence - the relational way people rely on each other for care and survival - offers an alternative approach. Ethics of care provides a cooperative, interrelated perspective instead of a hierarchical, power-based approach towards human rights.

\section{NOTES}

1. See, for example, Bubeck, 1996; Gilligan, 1987; Held, 2006a; Herring, 2013; Kittay, 1999; Noddings, 2002; Robinson, 2008, 2011; Ruddick, 1989; Sevenhuijsen, 1998, 2003; Tronto, 1993.

2. This chapter was previously published as "Race and Feminist Care Ethics: Intersectionality as Method" in Gender, Place \& Culture, 26 (5): 2-25. Published online May 2019.

3. Parts of this chapter were previously published in the article "Freedom and the Iranian Women's Movement" in Contexts, 18 (3): 14-19. Article first published online July 29, 2019; issue published August 1, 2019.

\section{REFERENCES}

Bubeck, D. (1996) Care, Gender and Justice. Oxford: Oxford University Press. 
Bunch, C. (2004) "A Feminist Human Rights Lens," Peace Review, 16 (1): 29-34.

Eisenberg, N., and R. Fabes (1998) "Prosocial Development," in W. Damon and N. Eisenberg (eds), Handbook of Child Psychology, Volume Three: Social, Emotional, and Personality Development. New York: John Wiley \& Sons, pp. 701-78.

Gilligan, C. (1987) "Moral Orientation and Moral Development," in E. Feder Kittay and D. T. Meyers (eds), Women and Moral Theory. New York: Rowman \& Littlefield, pp. 19-23.

Greenswag, K. (2017) “The Problem with 'Caring' Human Rights,” Hypatia, 32 (4): 801-16.

Hamington, M. (2001) "Jane Addams and a Politics of Embodied Care," Journal of Speculative Philosophy, 15 (2): 105-21.

Held, V. (2002) "Feminism and Political Theory," in R. L. Simon (ed.), The Blackwell Guide to Social and Political Philosophy. Malden: Blackwell, pp. 154-76.

Held, V. (2006a) The Ethics of Care: Personal, Political, and Global. New York: Oxford University Press.

Held, V. (2006b) "Feminist Moral Inquiry and the Feminist Future," in V. Held (ed.), Justice and Care. Boulder: Westview Press, pp. 153-76.

Herring, J. (2013) Caring and the Law. Oxford: Hart.

Herring, J. (2017) "Compassion, Ethics of Care and Legal Rights," International Journal of Law in Context, 13 (2): 158-77.

Kittay, E. F. (1999) Love's Labor: Essays on Women, Equality, and Dependency. New York: Routledge.

McPherson, J. M. (1988) Battle Cry of Freedom: The Civil War Era. New York: Oxford University Press.

Noddings, N. (2002) Starting at Home: Caring and Social Policy. Berkeley: University of California Press.

Nussbaum, M. (2001) Upheavals of Thought: The Intelligence of the Emotions. Cambridge: Cambridge University Press.

Robinson, F. (2008) "The Importance of Care in the Theory and Practice of Human Security," Journal of International Political Theory, 4 (2): 167-88.

Robinson, F. (2011) The Ethics of Care: A Feminist Approach to Human Security. Philadelphia: Temple University Press.

Ruddick, S. (1989) Maternal Thinking: Toward a Politics of Peace. Boston: Beacon Press.

Selznick, P. (1992) The Moral Commonwealth: Social Theory and the Promise of Community. Berkeley: University of California Press.

Sevenhuijsen, S. L. (1998) Citizenship and the Ethics of Care: Feminist Considerations on Justice, Morality and Politics. London: Routledge.

Sevenhuijsen, S. L. (2003) "The Place of Care: The Relevance of the Feminist Ethics of Care for Social Policy," Feminist Theory, 4: 179-97.

Timothy, K. (2004) "Human Security Discourse at the United Nations," Peace Review, 16 (1): 19-24.

Tronto, J. (1993) Moral Boundaries: A Political Argument for an Ethic of Care. Abingdon: Routledge. 
Tronto, J. C., and B. Fisher (1990) "Toward a Feminist Theory of Care," in E. K. Abel and M. K. Nelson (eds), Circles of Care: Work and Identity in Women's Lives. Albany: State University of New York Press, pp. 36-54.

Walker, M. U. (1988) Moral Understandings: A Feminist Study in Ethics. London: Routledge.

Young, I. M. (2011) Responsibility for Justice. New York: Oxford University Press. 